\title{
O CONTO NA MODERNA LITERATURA PORTUGUESA
}

\author{
JOÃO DÉCIO(1)
}

Se lançarmos um olhar, ainda que superficial, à produção literária dos últimos trinta anos, na Literatura Portuguêsa, salta aos olhos o número acentuado de bons e mesmo alguns excelentes contistas, todos a merecerem da crítica um estudo acurado; têm sido poucos os estudiosos, dentro ou fora do ambiente universitário, no Brasil ou em Portugal, que se têm debruçado sôbre o conto moderno. Já se fazem necessários estudos monográficos, temáticos ou não, tendentes a assinalar as tônicas do conto português na atualidade.

Contistas como José Rodrigues Miguéis, autor de Leah, Onde a noite se acaba, Gente da terceira classe, ou José Régio, de Histórias de mulheres e Há mais mundos ou Fernando Namora, de Retalhos da vida de um médico e Cidade solitária - e tantos outros - estão a exigir pronto pronunciamento da crítica.

Alguns fatôres têm prejudicado o conto, no interêsse que poderia despertar nos críticos e ensaístas: um certo preconceito inicial, consistindo em considerar o conto forma menor, dada sua brevidade; a dificuldade de estabelecer uma orgânica dos contos, através de critérios ou de métodos: abordar contista por contista? - Estudar a temática? - As linhas mestras? A estrutura?, tanto se fala hoje em dia na abordagem estruturalista.

Nós, inicialmente, pretendemos propor o problema, mas não deixá-lo simplesmente proposto. Vamos tentar estudar alguns contistas, numa série de artigos, de que êste é o inicial, para depois tentarmos estabelecer algumas preceptivas sôbre o conto moderno em Portugal. Algumas tônicas já podem aqui ser apontadas: o sentido trágico do conto português, sua vibratilidade poética; a linha urbana e rural, a exaltação e a ressurreição da problemática dos humildes e dos anônimos, seja no campo seja na cidade; a tentativa de universalizar os momentos únicos, os acidentes e incidentes; uma certa tendência ao ensaio de atitudes cosmopolitas e cosmopolizantes, na destruição das

(1) Professor-Regente de Literatura Portuguêsa da Faculdade de Filosofia, Ciências e Letras de Marília (Estado de São Paulo). 
barreiras geográficas, pela unificação, através dos dramas eternos do ser humano, que independem da nacionalidade; a linha erótica, importantissima e presente em contistas como Fernando Namora, Urbano Tavares Rodrigues e José Rodrigues Miguéis; a intensidade poética e a universalidade do conto feminino, encontráveis numa Irene Lisboa, Sophia de Mello Breyner Andresen ou de uma Agustina Bessa Luís; a extrema humanidade e a angústia enfim, do conto feminino de outras autoras. Enfim, há todo um mundo a ser desvendado, em tôrno dos contos e dos contistas, da atualidade portuguêsa.

É preciso começar e como sempre é difícil achar um comêço. Vamos tentar, estudando inicialmente os contos de José Rodrigues Miguéis. E vamos considerar conto por conto, de seus livros: Leah, Gente da terceira classe, e Onde a noite se acaba. O primeiro dêles encerra as narrativas seguintes: "Leah", "Uma viagem na nossa terra", "O Natal do Dr. Crosby", "Pouca sorte com barbeiros", "Regresso à cúpula da pena", "Dezesseis horas em missão secreta", "A importância da risca do cabelo", "Uma carreira cortada", "Saudades para a Dona Genciana" e "O Morgado de Pedra-Má".

Gente da Terceira Classe compreende as seguintes narrativas: "Gente da terceira classe", "O viajante clandestino", "Natal branco", "Arroz do céu", "O Cosme do Riba-Douro", "A Esquina do vento", "O anel de contrabando", "O crime perfeito", "Mucha plata", "A Dusseldorf, num pulo", "Perdão, Frau Schwarz", "Primeiro encontro com o transcendente", "Silvestre, os seus amôres", "A omelete se movos" e "Ite, missa est".

Onde a noite se acaba compõe-se das narrativas: "Enigma", "Morte de homem", "A mancha não se apaga", "O chapelinho amarelo", "A linha invisivel", "Cinzas de incêndio", "O acidente", "Beleza orgulhosa".

A margem, lembre-se de que José Rodrigues Miguéis é autor de alguns excelentes romances: Páscoa feliz, $A$ escola do paraíso e Uma aventura inquientante; da peça $O$ passageiro do Expresso e da narrativa: Um homem sorri à morte - com meia cara.

Mas, tornemos ao contista.

Em primeiro lugar é possivel ressaltar algumas características gerais do conto de José Rodrigues Miguéis: num sentido amplo muito embora o conto deva ser síntese, no autor em questão, quase sempre, tal síntese apresenta a facies psicológica das personagens: as ressonâncias internas, íntimas, sempre aparecem como corolário ou justificação das açōes, das atitudes, enfim, da dinâmica das personagens: é preciso acentuar que tais personagens não constituem meras ilustraçōes 
das ações (o que é reduzir e minimizar as grandes possibilidades desta fôrma narrativa, verdadeiros momentos de fulguração e de iluminação das criaturas, dos sêres humanos); é esta fulguração, esta revelação total em momentos únicos, que a crítica tem esquecido, preocupada com os aspectos objetivos do conto, reduzindo-o à pura ação, simples e simplòriamente. Os contos mais bem logrados de José Rodrigues Miguéis revelam que o conto é muito mais que ação, que esta é secundária, que é apenas o veículo dos grandes e reveladores momentos da face invisível da personagem. Ver e aceitar o conto como manifestação de uma dinâmica exterior em tôrno das ações e dos diálogos, é esquecer a outra parte, vale dizer, esquecer as amplas possibilidades que se abrem ao conto de introspeç̧ão, de análise interior. Centrar o conto nas ações, é finalmente, na base, eliminar a possibilidade de tal fôrma narrativa poder registrar momentos de universalização dos problemas e das situações das personagens. $O$ conto moderno, aliás, tem sondado a "psiquê", a alma humana, e mesmo tem conduzido a problemas da situação e mesmo a do absurdo, caso mais característico dos contos de Kafka.

Sòmente dentro desta perspectiva se pode entender e valorizar os contos mais característicos e expressivos de um José Rodrigues Miguéis, de um José Régio, de um Fernando Namora, de um Manuel da Fonseca ou de uma Sophia de Mello Breyner Andresen, para citar uns poucos entre tantos, da moderna literatura portuguêsa.

Esquecer, por exemplo, que muitos contos atingem a uma visão sintética e não raro poética da realidade, é conseqüência de pensá-lo como ação, pura e simplesmente.

Dentro desta linha poética do conto, é preciso lembrar que muitas vêzes é pelo que constitui ausência, a falta da personagem com relação ao mundo (não assunção, segundo Vergílio Ferreira), que o conto vale mais pelo que sugere, mais pelo que diz do que pelo que não diz. O grande conto é expressivo desta grande ausência do ser em relação ao mundo. E dentro desta perspectiva o conto de ação acaba sendo lançado para segundo plano, para se dar ênfase à análise, à colocação de uma dimensão introspectiva. Daí, a importância do conto residir antes. acima e além do diálogo e da ação. Antes ou além dela, revelando-se a narração e o diálogo como a possibilidade do dizível, restando o grande mundo do indizível (e da ausência), da conotação poética. E por isso que o conto vai, gradativamente, adquirindo uma fôrça, uma expressão, uma modernidade que o próprio romance não consegue acompanhar. Exigindo um profundo sentido de síntese, um como que conhecimento intuitivo, direto da realidade, o conto é fôrma de complexa realização, pois é o mundo da ausência, 
da busca, da tentativa de completamento. O conto narra o que a personagem é, mas esconde, ou melhor, sugere a grandioso e o sublime que ela pode ser. O conto é o grande sinal de ausência e o grande sinal de presença, mais aquela que esta. O conto, como visão sintética, consubstancia tôda a problemática do homem cuja vida não é mero somatório de momentos, que é um conjunto de grandes momentos de iluminação do ser a si mesmo, ao nivel do amor, da dor, da solidariedade humana, da compreensão, da comunhão. E é por isso que êle vale e é por isso que se revela difícil realizar o conto que rigorosamente mereça tal nome.

(continua...) 